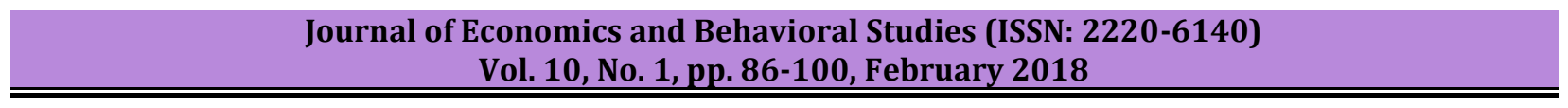

\title{
The Cognitive and Psychological Bias in Investment Decision-Making Behavior: (Evidence From Indonesian Investor's Behavior)
}

\author{
Sri Utami Ady \\ University of Dr. Soetomo, East Java, Indonesia \\ sri.utami@unitomo.ac.id
}

\begin{abstract}
The purposes of this research were to understand and analyze the behavior of the psychological bias experienced by investors in making investment decisions. Psychological bias experienced by investors led to wrong decision making and fatal losses. This research used qualitative interpretive phenomenology method to understand the phenomenon of decision making based on the perspective of investors. The result showed that: (1) The phenomenon of cognitive bias and psychological bias behavior occur in nearly all informants, (2) The Psychology bias could be divided by two types, namely: expected emotion bias behavior and immediate emotion bias behavior, (3) experience, knowledge of the capital markets and the management of good emotions determine the level of psychological stability and reduce bias behavior that could be raising the return.
\end{abstract}

Keyword: Cognitive bias, Psychological bias, Decision Making Behavior, Qualitative

\section{Introduction}

More investment decision making is influenced by investors' psychological factors than by companies fundamental or technical analysis. Ady, Salim, \& Susanto, (2010) indicates that dividend policy was not the dominant reason for investment decision making. Many studies have indicated that results analysis or psychological investors are very set against the accuracy of decisions taken (Loewenstein, 2000); (Ady, Sudarma, Salim, \& Aisyah, 2013) especially active individual investors who trade short-term stocks. The results of decisions are influenced more by the conditions and situations in which the decisions are taken.Behavioral finance is the application of psychology to finance, which has become an especially hot topic since the onset of the tech stock bubble in March 2000 (Pompian, 2006). Behavioral finance is an investigative study that attempts to explain market inefficiency using theories of psychology. One example of investor bias behavior in investment is overconfidence. Cunha (2015) showed that the powerful Investors in club setting were more overconfident, Showed greater better-than-average perceptions, and were more prone illusion of control and self-attribution than investors in the powerless position. Mitroi (2014)showed that investors are not as logical and efficient as we might think. The paper shows that behavioral biases are detrimental to the investment return of individual investor portfolios. As a direct influence of behavioral biases, the intuitive correlation between risk and return does not hold. Low-risk investments have the highest returns along with all dimensions of the market. The practical findings contrast the principles of efficient markets - the high risk is not correlated with the high expected return and low risk/safe investments have highest investment returns. Ady \& Mulyaningtyas, (2017) shows that if viewed from the theory of behavioral finance, efficient market hypothesis still need to be questioned because its assumption which assume investor always acting rationally, whereas in fact investor often behave irrational including in transactions of shares, although according to the result of in-depth interview to investor in capital market of Indonesia, many investors earn a return by using only technical analysis and historical data, indicating a form of weakly efficient market, with investors who invest more because of emotions.

Loewenstein (2000) divided the emotions of investors when undertaking stock transactions into two parts, namely expected emotion and immediate emotion. Expected emotion is the emotion that is anticipated to occur in investors when they are planning to buy or sell stocks. For example, when an investor buys a stock, he can imagine feeling happy when the prices of the stock bought increase as expected; similarly, he can imagine the sense of disappointment that he will suffer when the stock price falls unexpectedly. Immediate emotion is the emotion experienced directly by the investors. This emotion occurs with the emergence of news, both pleasant and unpleasant, causing panic to make purchases or sales. Both types of emotion make investors tend to behave in a biased manner, which results in them becoming unstable and acting excessively in response to an event. This study has attempted to capture the behavior of investors in response to various biases that occur when they face a wide range of events. Emotional instability causes investors to act 
irrational, resulting in un-optimum return, even inefficient portfolio selection, which ultimately results in notoptimal returns, even losses (Ady et al., 2013); (Han, Pereira, Santos, \& Lenaerts, 2013) this led to the curiosity of researchers to explore the behavior of investors in investing, especially behavior about cognitive and psychological bias as long as they transact shares. Research on the behavior of cognitive and psychological bias as long as the researcher's knowledge was rare, if any until now more positivistic studied using quantitative methods, so the needed of that more in-depth exploration of cognitive and psychological bias behavior can provide a more real and deep picture. The purpose of this study was to gain an understanding of the behavioral form of cognitive and psychological bias, as well as the consequences of such behavior on the level of investor profits.

\section{Literature Review}

Behavioral Finance: Behavioral finance is the application of psychology to finance, which has become an especially hot topic since the onset of the tech stock bubble in March 2000 (Pompian, 2006). Behavioral finance is an investigative study that attempts to explain market inefficiency using theories of psychology. It is observed that people often make mistakes and use assumptions that are not logical when dealing with financial matters. Behavioral finance has become a new paradigm in finance, supplementing the standard theory of finance by introducing aspects of behavior into decision making. There are two topics in behavioral finance, including Behavioral Finance Micro (BFMI), which test the behavior or bias of the individual investors that distinguishes them from rational individuals as in classical economic theory. The other is Behavioral Finance, Macro (BFMA), which detects and describe anomaly in the efficient market hypothesis that described in behavior model (Jahanzeb \& Muneer, 2012). This study is focused on BFMI that the study of the behavior of individual investors in order to identify the psychological bias and cognitive bias as well as investigating the behavior of asset allocation so that it can suppress biases in the investment process.

Expected Emotion: Expected emotion is the emotion or feelings that are expected to happen after the result of the decision taken has materialized but not at the time of decision making (Pompian, 2006). As an example, potential investors who will buy stocks can already imagine the feeling of disappointment if they had purchased stocks that declined and vice versa. Expected emotion can be prepared before the decision making, such as the mental readiness of a trader to lose his or her assets in the stock market if the stock price falls.

Immediate Emotion: Immediate emotion is the emotion experienced by investors or traders at the time of decision making. Immediate emotion is divided into two categories, namely (Pompian, 2006): a) immediate integral emotion, such as the expected emotion that comes from thoughts based on the consequences of a decision but occurs when the decision making is finished, so it causes a variety of biased behaviors as well as cognitive bias, and b) incidental emotion, which is also experienced at the time of decision making but is sourced from an objective situation that does not relate to the decisions taken. Mood misattribution often causes the occurrence of incidental emotion. The environmental factors that cause mood attribution are: a) the weather Hirshleifer \& Shumway (2003), Cao \& Wei (2005), Hu (2008), Yuksel \& Yuksel (2009); b) the biological cycle of the body; c) sleep disorders; d) the lunar phase; and e) social relationships (Muneer et al., 2016).

The range of psychological and cognitive biases is as follows:

- Overconfidence bias is a belief that is not based on intuition, adjustment, or a person's cognitive ability. A survey has shown that people overestimate the capabilities of predictions and the truth of information and are likely to have difficulties in estimating the likelihood of occurrences. That is, people think they are smarter and have better information than the actuality (Daniel et al. in (Thaler, 2005); (Pompian, 2006). Overconfidence could affect investment decisions. Overconfident investors not only take wrong decision for themselves but also exert a strong effect on the overall market. Overconfident investors are likely to overtrade as a result of the belief that they possess better knowledge than others. Investors' overconfidence due to ignorance, passiveness, and a lack of understanding of the performance of the investment company might cause them to underestimate the history against the risks, resulting in a portfolio that cannot expect a bad performance.Jannah \& Ady(2017)shows that research conducted on young investors in Indonesia shows an overconfidence that has an effect on investment decision making. 
- Cognitive dissonance bias, mental or psychological discomfort, is experienced by a person when there is a discrepancy between newly obtained information and the previous understanding; it is also known as an imbalance when cognitive contradictions occur. Cognitive dissonance could lead to investors holding shares with losses that should be sold because they want to avoid the heartache associated with the recognition that they have already made a bad decision. Cognitive dissonance could lead investors to continue to invest in the securities owned despite dropping prices (average down) and could cause investors to be "behaving ducks" (herding behavior).

- Familiarity. When confronted by a new phenomenon that is not consistent with the classification that has been built, people still classify and represent it with information that is already owned. This case gives them a fast response to help them to survive. Sometimes, new stimuli that are similar are considered to be representative of the familiar elements or classification already formed, despite being drastically different, so this reflex classification could fool people into creating a sense of wrongness and being biased against all future interactions with the elements (Pompian, 2006).

- Availability bias is a cognitive bias whereby people tend to make an estimation of possible outcomes based on how close or familiar results are that occur in our lives. There are four different availability biases, namely: a) retrievability, in which the idea is to take the easiest and the most credible option; b) categorization, in which investors choose investments based on a list of categories that are easy to remember; c) a narrow range of experience, whereby investors will tend to choose investments that fit in with their life experiences; and d) resonance, in which investors tend to choose investments based on the matching of personality or characteristics that relate to their behavior.

- Self-attribution bias is the tendency of individuals to ascribe the success experienced to internal factors while the failures experienced are due to external factors. This bias causes investors a) to take a bigger risk after a long period of success that causes excessive self-confidence (overconfidence); $b$ ) to trade too often (overtrading) with high risk; c) to hear just what they want to hear; and d) to hold a portfolio that is under diversified, namely a simple diversified portfolio.

- Loss aversion bias is a type of emotional bias whereby people feel the urge to avoid greater loss than benefit. According to behavior experts, the pain caused by losses is far greater than the fun resulting from being lucky. Many experiments by Thaler and others have shown that two positive experiences are needed to overcome one negative one (Hagstrom, 2010). Investors who deny loss-making become excessively conservative, which could also affect them directly by causing them to hold onto bad shares and sell shares irrationally.

\section{Methodology}

Phenomenology as A Method of Understanding the Cognitive and Psychological Behavior of Investors: The paradigm that was appropriate to understand and explore the biased behavior of investors was the interpretive paradigm. The interpretive paradigm places more emphasis on one's meaning and interpretation of a symbol (Creswell, 2007). The purpose of the research in this paradigm was to understand and explore to then interpreted the meaning, not to explained and predicted a relationship as in quantitative research. In general, qualitative research aimed to understand the phenomenon of what was experienced, why he experienced it and how he experienced it.

Site, Informant, and Data Collection: The research site was an individual investor who traded shares on the Indonesia Stock Exchange. The reason of site selection was individual investors who traded stocks with online trading so that emotional upheaval will be perceived by the investor himself. Research that used the behavior of individual investors as informants in non-positivistic studies was relatively small, and there was relatively little research exploring the behavior of cognitive and psychological bias on individual investors. The informant's search was done by using sine qua non-method which selects the informant by looking at the qualification that has been determined. Informant was an active investor who had invested in shares for at least 5 years and not part of the company (insider). In-depth interviews took place in a place agreed by the informant within a period of six months. The process of collecting data in an interactive way, with a duration of 1 to 2 hours depending on the conditions during the interview. To get key informants who meet the criteria, the researchers obtained information from Indonesian Stock Exchange, next, a search for informants was conducted using the snowball technique. In-depth Interviews were conducted three to five times of indepth interviews until they reached saturated depends on the subjectivity of the researcher and the research 
issues that they intended to investigate (Bogdan \& Biklen, 2003; Glaser \& Strauss, 1967, 1967; Egon G Guba \& Lincoln, 2004).

In qualitative research it is not intended to draw conclusions in general but to explore the experience of each informant that is unique, so that the importance of qualitative research is not the size of the sample, but the depth and uniqueness of the perception and experience of each informant (differentiate the large samples of the quantitative research for the sake of generalization). In accordance with the principle of phenomenological research, the researcher must be able to dig deep with information sources as much as possible. This method also requires the participation of researchers directly on the subject in the field, therefore researchers were not enough just by interview, but become a key instrument in this study. According to Guba \& Lincoln (1994), the researcher benefits as a key instrument because of its responsive and adaptable nature. Researchers as instruments will be able to emphasize holistic emphasis, develop knowledge base expansion, processual emulate, and have opportunities to classify and summarize, and can take advantage of opportunities to investigate special or peculiar responses. Data collection in this research was done by in depth-interview, observation, and documentation. The informants in this study are as follows:

Table 1: Demographic Data The Main Informant

\begin{tabular}{llllll}
\hline No & Name & Age & Sex & Education & Marital Status \\
\hline 1. & I-1 & 48 & M & S2 & Married \\
2. & I-2 & 37 & M & S2 & Married \\
3. & I-3 & 55 & M & S1 & Married \\
4. & I-4 & 21 & M & High School & Unmarried \\
5. & I-5 & 43 & F & High School & Married \\
6. & I-6 & 44 & F & S2 & Married \\
\hline
\end{tabular}

Source: Processed data, 2017

The demographics of the informants are as follows. The 6 informants were investors who already have at least 5 years' experience: 4 men and 2 women, Their aged between 21 and 55 years. Their buying and selling behaviors were observed by conducting in-depth interviews (Table 1). Their buying and selling behavior was observed and the in-depth interview was conducted.

Data Analysis Technique: The methods of data analysis followed the phenomenological method of Moustakas (Moustakas, 1994). To support the validity of the data, validity, and reliability qualitative tests were performed, namely relevance or transferability, credibility or trustworthiness, authenticity or confirmability, and dependability (Shenton, 2004); Daymon \& Holloway, 2007).Transferability refers to external validity. The transferability criteria derived from the results of this research are related to the academic literature in the context of investor behavior. Credibility/trustworthiness in this research was obtained by triangulation, member checking and external audit, which matches or integrates various types of data obtained from the in-depth interview, observation, and documentation. There were several kinds of triangulation conducted in this research namely: (1) triangulation of data, triangulation of data was done by two ways, that was between time data for each site and between site. Between time Data was done by matching the verbal expression obtained from the in-depth interview with each informant from time to time to produce consistent information. To conduct inter-site triangulation, the researcher combines and analyzes the information obtained from the six informants to find a match for emerging themes. (2) theory triangulation, triangulation theory was done by comparing the results obtained in the field with existing theory. (3) triangulation of data retrieval technique. Triangulation technique was done by aligning the results obtained from data collection techniques by way of in-depth interview, with observation and documentation support.

Member Checking. Member Checking conducted in this research was done by showing data or information, including interpretation of the researcher, written in the form of contact summary sheet or interview transcript to an informant to be commented, approved, and the need for additional information which was deemed necessary. Subsequent comments, reactions, reductions or additions were used to revise the contact summary sheet. The end result of this study was obtained after the approval of the informants.The external 
audit was asking people outside the research (those who were not involved in the entire research process) with an expert, a lecturer, peers, and so on to produce final conclusions about the observed phenomenon.

Authenticity or confirmability. Confirmability/authenticity refers to the level of research results could be confirmed by others(Emzir, 2010). Authenticity could be achieved when the research was conducted fairly and far from the bias of the researcher or called objectivity. Researchers bias attempted to minimize with epoche and bracketing. Bracketing was done by explicitly demonstrating that the resulting themes were obtained based on the statements of the informants from the interviews.Dependability, as (Guba \& Lincoln, 2004)suggested that the term reliability in quantitative research means dependability in qualitative research. Shenton, (2004) states that reliability could be achieved by detailed reporting, which allows the next researcher to repeat the work, which, whenever possible, in the sameresults. The qualitative reliability aspect refers to the clarity of consistent analysis procedures and could be used by subsequent researchers.

\section{Findings and Discussion}

Expected Emotion: The results showed that nearly all the investors experienced a psychological bias in transacting or investing. These biases arose as a result of the existence of emotions that accompanied their stock buying and selling behavior. Loewenstein (Loewenstein, 2000) divided the emotions of investors when undertaking stock transactions into two parts, namely expected emotion (an emotion that is anticipated to occur) and immediate emotion. Expected emotion is the emotion felt by investors when about to buy or sell shares. For example, investors can already imagine the feeling of happiness if the stock price increases, although the current purchasing decision has not yet been implemented and the investor can well imagine the pain that will be experienced if the stock price decreases. Expected emotion will progressively decrease with increasing investor education and experience, especially for investors who want to learn. Expected emotion is the emotion that investors would expect when buying/selling stocks. Expected emotion occurs before the decision is made (Loewenstein, 2000). An example of an investor can imagine the pleasure he gets if the stock he buys has risen in price, or he can also imagine the sadness that will be experienced if the purchased share decreases in price. The high degree of expected emotion depends on how accurately the investor's analysis takes on the decision. The accuracy of this stock analysis is often internalized by behavioral biases such as the following:

A. Overconfidence is a belief that is not based on intuition, adjustment, or cognitive ability. The concept of overconfidence is based on cognitive psychological experiments and surveys in which someone tends to overestimate the capabilities of the predictions and the truth of the information belonging to them (Pompian, 2006). Some studies have shown that investors are likely to be overconfidence regarding their investment ability, particularly investors who make very simple predictions. This overconfidence type is called prediction overconfidence. The implication of this behavior is that investors will underestimate the risks to their portfolio, so they take decisions that involve excessive risk. They often take the wrong decision. For I-1, Overconfidence is someone who makes decisions and is often wrong or not in accordance with his predictions. For I-1, if someone is confident with the decision he takes by doing some fundamental and technical analysis and the decision is taken that is true to get the maximum return, then this is not overconfidence. As he experienced in stock transactions, I-1 has always been considered overconfidence due to overconfidence without regard to the analysis of some stock analysts. For other investors who are friends of I-1, then I-1 will be considered overconfidence. But for I- 1 alone, as long as the decision is correct, it is not an overconfidence, but a reflection of the learning outcomes and financial knowledge it has. The I-1, which is an investor with an S2 education in the capital market field, has the knowledge that can be used to equip it in a stock transaction; on the other hand, twenty years of experience as a stock investor simply provides a valuable experience in various economic situations. Some of the answers from informants showing their overconfidence are:

"People often says that I was too overconfidence. Well, sometimes, others who could only judge ourselves. Because people say, this right has not been correct, But, all of this was rational, and it was in my experience, ma'am, $80 \%$ was correct. Then I bit have made it rather conservative with an estimation. My prediction it was until (the stock price of ASTRA) 48 thousand, even reach 50 thousand, that didn't mean overconfidence, but for investors, I calculated that had said too confident, I was the one that is not too fond of online information, according to friends, it was too confident because it felt unnecessary information. Because I felt knowing their knowledge. Once again, though 
it was not $100 \%$ correct, so for me it could judge other people, I was considered overconfidence. For me, if that was correct, it wasn't. People were said to be overconfident, it means to me he was overconfident and he often damages, but if he is confident and he is fortunate, often profit rather than loss, in my opinion, it's not going in there. Because of the principle of overconfidence was a person said to be overconfidence if he trades and often trades, he is often wrong. He's against the market, he glorified his science, but it was wrong, the count was wrong. That's what, in my opinion, seems to be overconfidence. Usually, the characteristic of overconfidence is, that person does what is called an overreaction."(I-1. Wc. 0v1).

Overconfidence causes investors to feel no need to conduct further in-depth analysis so that investment decisions aren't maximized and the bias resulting in losses is overcome. Almost all investors experience overconfidence at various levels. The higher the level of overconfidence of an investor, the more frequent prediction errors, and ending to a loss. An overconfidence investor will tend to over-transact, feeling he can beat the market. This is shown on I-5 which is a day trader. Every day I-5 trading 5-10 times. With an average return rate of $30-40 \%$ per year with more than twenty years of trading experience, it shows the average performance level of its portfolio as the 21-year-old I-4 and has far less experience. Not to mention the psychological pressure is borne by the I-5 in stock trading that should monitor stocks during trading that would cause its own stress. The findings of the existence of overconfidence in the behavior of investors are the same as the findings of Yates (Yates, 1991), (De Bondt, 1998), (Campbell, Goodie, \& Foster, 2004), (Ady et al., 2013), and (Ady, 2015).

B. Representativeness bias is a cognitive bias that people tend to classify objects according to what they awaken in their mind. When encountering a new phenomenon that is not consistent with the classification that was made, they still classify it according to their previous thoughts, define the categories, and form the basis of the notion of the new phenomenon(Pompian, 2006). This is a way to process new information by combining a reflex with an understanding of the relevant past experiences. Sometimes, a similar new stimulus is considered as being representative of the familiar elements of the classification that has already been formed, though, in reality, it is different, so the classification of this reflex could be deceptive, creating a sense of a new element that has always existed and caused a bias against all future interactions with the element (Pompian, 2006). Some investors from this research experience representativeness, such as I-3 which consider a big company, its shares must be good. They can not distinguish between a good company and a good stock. Good company is not necessarily good stock. Good company is a nice big company, owned by the government, has a big building, often advertised on television. But they do not see the fundamental and technical analysis. What they capture is a big company, then they buy the stock of the company. Good stock is the stock of a company that is currently good to buy is marked with a lower intrinsic value than the current market price. Or with the term "undervalue". Investors buy stocks in the hope that stock prices will rise in the future, and generally, share prices will move in line with their intrinsic value. If the intrinsic value of a stock is now below market value, then the stock price will soon fall because the stock is no longer undervalued, but "overvalue". And buying overvalued stocks will not generate any potential profits for those shareholders.

Representativeness is also associated with how familiar we are with the company. In general large companies are very familiar with the community so that stock selection is still concerned with how familiar the company is to investors, such as the results of interviews with the following I-1:

"Some psychological aspects often appear in the behavior of investors was what we knew in representativeness bias, that was bias tended to pick great stocks, if the shares of Bank Century were wholly good if the shares of Gudang Garam was wholly good. Some types of investors, particular investors of pension funds, many of them were affected. They just wanted big company stocks. It was representativeness bias. If his company was definitely big, is nice. Or also people buy familiar stocks, stocks that he knew. He does not want to buy stocks he is not familiar with. Oh, he knew shares of Gudang Garam are known, Astra he knew, he chose those stocks. It had to do with that representativeness."(I-1. Wc. Rp1).

Investors should be able to tell the difference between a good company and a good stock. A good company is a company that has a good image, typically a government-owned company has a large 
building, and is already well-known and familiar to the community. This finding is in accordance with Shefrin (Shefrin, 2001), (Shefrin, 2005), (Lucey \& Dowling, 2005), and (Ady, 2015). Meanwhile, a good stock is a company that has a good stock of current, that is, undervalued stocks. Investors who have biased behavioral representativeness tend to diversify their stocks moderately and choose a good company rather than good stocks, so they are likely to suffer losses this is also in line with the results of Badshah et al research (Badshah, Irshad, \& Hakam, 2016)that also shows the representativeness bias affect the investors decision making.

C. Loss aversion is a psychological bias (emotional) whereby generally people feel a greater urge to avoid loss than gain benefit. A number of studies on loss aversion have shown that the probability of experiencing loss psychologically has twice the strength of the motivation of the probability of gaining the benefit of the same amount (Novemsky \& Kahneman, 2005); (Pompian, 2006).Loss aversion bias could make investors avoid risks when evaluating the possibility of profits because avoiding losses is considered to be more important than gaining profits. When investments start to generate profits, lossaverse individuals will quickly lock in their profits and sell their shares because of their worries that the market will reverse course and take their profit. This is a problem of releasing stocks prematurely to protect the potential profit. In general, loss aversion causes investors to hold losing stocks and sell profitable stocks, making their return portfolio sub-optimal. A manager with a higher degree of loss aversion tends to take less risk, so the return obtained is also lower (Bodnaruk \& Simonov, 2016). Experience of the following I-2 shows the presence of loss aversion behavior that is not realized. Here's an excerpt from an interview with I-2 when asked about the loss he has experienced:

"Well if selling decision until now I never experience panic selling. I am indeed a trader, but I never get cut loss. After the goods down, I let it there. I never suffer loss. If I suffer loss, I never gain on realization. Yes, I have my stuff now that I let it impinged. I let it. For example, my cases, I've told you the story that in the past the trader of Cibinong's cement, ma'am, the prices were 275, I bought that time with the price 600 , the price then go up, I got many profits, went up to 800 , ha 1200 , declined again until 300 rupiah. Finally, I saved it". (Wc. I-2. Ps6. p3).

Loss aversion causes investors to hold a loser's stock for years, because not wanting to lose, but he is not aware of the magnitude of the opportunity cost sacrificed by letting hold the wrong stock for a very long time. If the investor sells the stock then the chances of getting a better stock will be gained rather than holding stocks with high uncertainty to rise, especially for penny stocks.

D. Cognitive dissonance is a psychological bias in the form of the mental/psychological discomfort experienced by a person when there is new information mismatch in the sense that it is believed. Cognition in psychology represents attitudes, emotions, beliefs and values, and dissonance. Cognitive dissonance is an imbalance when cognitive contradictions occur.Cognitive dissonance could lead to investors: (1) holding a losing stock that should be sold, because they want to avoid the heartache associated with the recognition that they have made bad decisions; (2) continuing to invest in the securities owned despite their falling prices (average down) to confirm their earlier decision to invest in securities without adjusting the objective; and (3) behaving like ducks (herding behavior), whereby people avoid information that could thwart their earlier decision so that too much information is filtered, causing investors to listen to a shared decision and cause an abundance of information to take over their decisions (Pompian, 2006). Here are the results of interviews with I-2 that show the existence of cognitive dissonance behavior on stock investors:

"Well, if selling decision, until now I never experience panic selling. I am indeed a trader, but I never get cut loss. After the stocks down, I let it there. I never suffer a loss. If I suffer loss, I never gain on realization. Yes, I have my stuff now that I let it impinged. I let it. For example, my cases, I've told you that in the past the trader of Cibinong's cement, ma'am, the prices were 275, I bought that time with the price 600 , the price up....up..., I got many profits, went up to 800,1200 , declined again until 300 rupiah. Finally, I saved it". (Wc. I-2. Ps6. p3).

"For example this, oh if I was lost, I suffer a loss, said that the stock price was 8000, I got in with 8000. Oh, it turned out, went down till 7800 , went down 200 , held down again to 7600 , well, I took it again. I sold it when the prices were already 7800. It was finally a match. The first one I just let it. It 
was the same, right? The stock was the same. I can get it. It is like this, I bought it in 8000 . Down to 7800 , down again to 7600 , talking fundamentals, oh this turned out to be too cheap, I did. Let's say I bought 1000 sheets, I priced at 7600, I bought 1000 sheets more. The price of 7600, at a time when the price went up to 7800, I sold 1000 sheets. If the normal price was above 8000 I sold those more than 1000 sheets. It was no name, right whether 7600 or 8000 . The important thing when I bought, I had 1000 sheets "(Wc. I-2. Ps7. p4). (Average down/cognitive dissonance type 2).

The results of this research were the same as the findings of Chang et al. (Chang, Solomon, \& Westerfield, 2016), (Ady et al., 2013), (Ady, 2015) in that cognitive dissonance tends to appear in individual investors' behavior.

E. Availability bias is a cognitive bias that people tend to make an estimation of possible outcomes based on the closeness or familiarity of resultsoccurring in their lives.

"It was just easy, active shares traded, the shares were obvious, state-owned enterprises was definitely I bought. Obviously, it was the meaning of BCA Bank, Telkom was obvious, right? I chose companies that were already clear. In theory, we had to read his financial statement, right? If the financial statements, I were not an accountant, so I didn't read it too much if my child might be possible, yes, but I were not. But it was clear if the gas companies of the country, was presumably BCA Bank, it was indeed didn't play the feeling, but it was visible if the company was profitable, turned out to be correct also."(Wc. I-3, Ab3, p. 2)

F. Self-attribution bias is the tendency of individuals to describe the success experienced as being due to factors from inside while describing the failures experienced as being due to factors from outside.

"They did the analysis, but sometimes unrealistic. No empirical according to our view, but it was according to their view of empirical. It was indeed that we were a science which was opposite those traders. If we essentially empirical, if they didn't eh science filing, it was surely waking up because of dreaming, then trading buys immediately. Yes, it included them who likes a high risk, they looked for justification. Mother where her dream could prove him and they have the satisfaction if, oh this is appropriate to my dream. Looking for justification. In theory, it is looking for justification. It was hard." (Wc. I-2, I4, p.1)

Immediate Emotion: Immediate emotion is the emotion experienced by the investor or trader at the time of decision making. Immediate emotion is divided into two categories, namely 1) immediate integral emotion, 2) Immediate incidental emotion

Immediate integral emotion: Immediate integral emotion is the emotion that comes from thoughts based on the consequences of a decision but occurs when the decision making is finished, for example, fear that is experienced directly by investors when thinking about the decline in the value of stocks. The immediate integral emotion in this research was stimulated by rumors, the influence of friends, drastic changes to the market situation, the political situation, macroeconomics, foreign investors, and brokers. Immediate Integral Emotion is a direct Emotion that occurs during decision making, induced by a cause that is still related to the decision taken. The causes of immediate integral emotion from the results of this study are as follows:

A. Rumor is emerging news, and investors take the decision to pay attention to the news. Regarding variable rumors, among other informants I-2, I-3, I-4, and I-5 took the decision to pay attention to rumors:

"Yes we have seen in the past, who enter today, how was the volume? Still see it also, and this rumor. The thing which made that strong is the rumor, right? We read every day. Yes, we have seen our chart. If foreign companies were like go to JU, RE, JK, we just let it”. (Wc. I-5, Ab1, p. 1).

B. In decision making, not a few investors rely on what is said by friends. Therefore, the influence of friends is also one form of stimulus for investors to sell or buy shares. One informant who felt stimulated by the influence of friends was I-5:

"Usually if there's any good news, we bought it. This company would like to announce the rising profits, bought it. Usually, friends do so. The announcement of a dividend."(Wc. I-5, Ps6, p. 3) 
C. Drastic changes in the market are market conditions that change unexpectedly either due to a crisis in other countries or the existence of dividend announcements, which can make investors sell or buy shares. The informants who felt stimulated by this variable, among others, were I-1, I-2, I-4, I-5, and I-6:

"Usually if there's any good news, we bought it. This company would like to announce the rising profits, bought it. Usually, friends do so. The announcement of a dividend." (Wc. I-5, Ps6, p.3)

"Usually we lose it because of an issue, or indeed there is a crash. So the analysis is no longer valid. World stock, or world economy, like yesterday, Spain it. Spain in 2011 but not too crisis hell, which he said Spain too oversees the economy in Europe. But the profit (in stock) is pretty much, on top of inflation a lot you know "(wc.I-4.Id4.p1)

D. The political situation of a country could affect investors' behavior in selling or buying new shares. As an example, following the Bali bombing or the terrorism event at WTC, many investors sold their shares. The informants who felt that the political situation stimulates investors' behavior were I-1, I-2, I-4, I-5, and I6:

"Ever, how much it was, probably $10 \%$, because of that loss is usually due to an issue, or there was a crash. So his analysis was no longer valid. The stock of the world, or the world economy, like yesterday, Spain it was. Spain in 2011 but not too hell crisis, which he said Spain was to keep an eye on the economy in Europe. But the perks (in stock) pretty much, inflation much above." (Wc. I-4, Id4, p. 1).

"When WTC immediately plummeted, oh not got around to sell, miss, the next it was immediately down about $50 \%$. We waited, not had enough time, we wanted a cut loss, but we were afraid. In 2001, it was really long, maybe, before 2007 it was severe, miss. The return of one year, after the WTC, was destroyed." (Wc. I-5, Ps4, p. 3)

E. The macroeconomics of a country will greatly affect the progress of the capital market because one of the indicators of the country progress is the level of Indonesia Composite Index or Indeks Harga Saham Gabungan(IHSG) in the capital market. The development of national income, the industrial sector, the rate of inflation, growth, and the exchange rate of the rupiah are instrumental in the development of prices in the stock market.

F. The role of macro variables in decision making by investors can be seen on the results of interviews with informants in the following:

"Yes anyway been keen on now the rupiah strengthened. The first, the greatest was mining, it's definitely a banking drove fast. Anyway, we saw macro. " (Wc. I-5. Ab4. p3).

"It used to be, now I choose stocks, I think this country is roughly what it takes. If I still have any logic. Indonesia is developing countries. So the basic needs of the industrial sector that are definitely growing. In 1996. I basically just liked that. The industry was definitely growing, definitely needed cement, needed to build it. Yes, had to need a home, right, there was properties cement, mines, gold, oil, and gas there, yes I bought all, Only logic things. That's it. I just wore my instinct, because I didn't know. I didn't know much about the fundamentals so that's how it was, just me ... how I call it, just an instinct."(Wc. I-2. Ab4. p3).

G. Foreign investors also play an important role in influencing the behavior of local investors. Most local investors use foreign investors as one of the indicators of stock selection. If the shares of a company are in great demand among foreign investors, local investors consider this to be a signal that the prices of the stocks will increase. Likewise, if foreign investors sell stocks, they will be followed by local investors, because usually, foreign investors perform transactions of purchases or sales of shares in large quantities, resulting in a large-scale decrease or increase in the stock price. The following are from the interviews with some of the informants:

"If foreign investors came in, wow, this was a green light, miss, it means this share was interesting, yes I've adherents. Later, when the chart already at the highest point, I sold it, but at times have not been the highest point, I sold it." (Wc. I-5, Ps5, p. 4) 
$\mathrm{H}$. The role of brokerage companies also affects investors' behavior. Many brokers provide fundamental analysis services to assist investors in their decision making. Therefore, sometimes investors try to obtain current information from the broker, especially for traders, both day traders and swing traders:

"When it is hot just now, I analyze it as I was a student, but the analysis is limited, oh this week how much definitely it will increase, so I was just thinking the margin only. How many downs and so on? Not using the fundamental, because my knowledge is very limited. Even children who were also in the corner was also so. It was because knowledge is limited, so. It was technical, purely technical because the timing technically was supported by the broker. This broker took over the technical, candlestick, then double head, shoulder, he proved that, in a wide variety."(Wc. I-2, Ab2, p. 2)

The results of the in-depth interviews with the informants indicated that the variables above are stimuli that encourage the emergence of integral immediate emotion, causing behaviors and irrational decisions. The political or economic events in a country have a very strong psychological effect, such as the Bali bombing and the tragedy of the World Trade Center attack in the United States, and can very easily create a sense of panic among investors, who take a massive share sale action that is particularly disturbing to the stability of the capital market as a whole.

Immediate Incidental Emotion: Immediate incidental emotion is immediate emotion experienced by investors because of the mood changes that are caused by internal and external occurrences. The stimuli that are internal in this research were triggered by 1) body condition and 2) sadness, whereas the external conditions were triggered by 1) routine work, 2) social factors, 3) family, 4) lunar phases, and 5) the weather.

Immediate-incidental emotion is a direct emotion induced by things not related to the decision taken but from the mood of the investor. Immediate incidental emotion causes mood changes that greatly affect the stability of investors' psychology. The things that cause mood changes are as follows:

A. The accumulated work routine leads investors to focus less on carrying out investment analysis so that when it is imposed it affects the return generated.

"The mood was definitely not making the last first because my nature was not the main work, ma'am, the most influential was the influence of the main work. It was very influential. So when I was loading with my main work, so often I stopped first for trading. It was the most affected me. The second was after a considerable loss I would not want to make it riskier fare to avoid the risk intensely. For example, in 1998 I lost 80\%, I had stopped two years, after that, I did it again. If I still tended to beat it, and it definitely precluded there must have been a little bit of influence." (Wc. I-1, Ps11, p. 2)

B. The condition of the body of investors who did not fit could also cause less investor focus on implementing the investment analysis.

"After the considerable loss, usually, I have stopped first, in a long time, if I was sick, I would not play it, I was too lazy if I got sick or my son was sick." (Wc. I-5, Ps10, p. 3).

C. Social factors could also provide a stimulus for investors in decision-making. This was as described by informants as follows:

"I talked about my friends' experience who plunges in stocks. Most of my friends were women, ma'am. My investor's friends, ma'am. Started from morning until afternoon, they were in that broker, not the broker, he invested. Thus began the morning until the afternoon they were there, came out just to eat there again, every day like that. It was usually most of the chines. And they were usually more risk-taking than I did. There I wonder, that's what I saw, ma'am was a lot more of my friends were women investors than men. When I came to the broker, ma'am, I did not say to investors outside of the broker. If the broker, it's that many were. And they were an incredible risk and most of them who played short term. Yes, I was also somewhat less plausible, but yeah that's what I see there. They were sometimes employers, have a workshop, have a shop, yes like that. Her husband may have been successful and so on. "(Wc. I-1. Ps12. p3)

D. Problems in the family could also be a stimulus for investors, leading investors to think more about the problem and focus less on taking decisions. 
"...For example, in 1998 I lost 80\%, I had stopped for two years, after that, I did it again. If I still tended to beat it, and it definitely precluded there must have been a little bit of influence." (Wc. I-1, Ps11, p. 2)

In general a positive mood tends to encourage investors to make a positive assessment, so instead a negative mood encourages investors to make a more pessimistic assessment than when they are in a neutral condition, in accordance with (Damasio, 2006), (Loewenstein, Hsee, Weber, \& Welch, 2001), (Ady, 2015)and (Teng \& Liu, 2013), who suggested that positive emotions due to the effect of a preholiday period produce significantly higher returns.

"If I were that if my condition was not in the mood, I was not plunging, it was influential, certainly, at least in acuity in analyzing was definitely experience the difference, we did not want to buy shares when I am in not good condition, for sure, so I would not plunge in stocks." (Wc. I-1. Ps10. p1)

E. For most people, the weather changes very influential on health and mood of the person. So also for investors, the weather changed indirectly also affected the performance of investors in the capital markets.

"It was not the weather, ma'am, as rainy season. For me, it was not. But there was actually the theory. Just used logical thinking, ma'am. If the rainy season continued, sure I bought the food and beverages company, it definitely would be a disaster. So if there was a disaster, Indomie was definitely the hard sell. Yeah, it had to go up later."(Wc. I-2. PS3. p3).Research on the effect of the weather against the return of shares in accordance with $\mathrm{Hu}(\mathrm{Hu}, 2008)$, (Cao \& Wei, 2005), (Hirshleifer \& Shumway, 2003), (Dowling \& Lucey, 2008).

Based on the investor behavior above, it can be suggested that investment decisions are filled with psychological bias and are therefore irrational. This bias was progressively reduced by increasing the education level, experience, and maturity of one's emotions to produce more rational investment decisions. There is important too, to pay attention to moral values in transacting shares. Ady (Ady, 2018) points out that one of the keys to successful investing is psychological calm that investors get for keeping ethical moral values in stock trading, such as not doing margin trading, short selling, false demand, and supply, etc. On the demographic side, the 48-year-old I-1 has an S2 education in capital market, having 17 years of experience as an investor will have an average annual gain of $80 \%-100 \%$, while I-2, 37 years old, S2-educated and experienced for 15 years as an investor, has an average profit per year of $30 \%-40 \%$ per year. Both investors have an equally high education but have a very high return difference as well. Based on the observations of the researchers, these two informants have personality differences. I-1 is a very analytical and calculating investor. In every investment decision making, a thorough analysis is performed, from macroeconomic fundamentals analysis, industry analysis, company analysis to company financial analysis. From year to year based on his experience, he always evaluates the performance over the years. The magnitude of the experienced role for I-1 in the following sentence:

"So indeed if in the capital market, the experience factor is remarkable. It is also important, it is important to keep our emotions. If we are not familiar with the capital market, we can be "crazy" there. Like crazy. Why, because of the price of shares that should go up, down incredible. Not to mention we are talking fried stocks. If we are people who do not have a stand when stocks rise, we are incredibly happy, stock prices down, we are afraid extraordinary, we stress ". (Wc.I-1.Pngl.)

The experience of making an investor increasingly knows what to do in conditions that are limited. A high experience will create an intuition for a person to endure within time constraints. What is needed is a better understanding of the dynamically changing market conditions and how to make adjustments based on current conditions. Because it is important for investors to always update the science and learn from the experience in the past. Informant 1 has a better level of emotional stability than others based on experience, education so as to conduct a more rational analysis and generate an average return per year of $80 \%-100 \%$.

Model of Cognitive and Psychology's Investor Behavior: Based on the results of interviews with informants can be generated a model of investor behavior as follows:

A. Immediate Integral emotion is a direct emotion that affects investor behavior triggered by events related to the decision to be taken. Investment decisions are decisions that are full of risk and uncertainty 
because it will require caution but also the courage to take risks. Developing rumors in the community, or deliberately launched by certain parties, the influence of friends at the time of investment decision making, drastic changes to market conditions that cause panic, political situation and conditions are less stable / changing, changes in macroeconomic conditions, the massive influx of foreign investors into the market, and the influence of brokers strongly determines the emotional state of investors.

B. Immediate Incidental emotion is a direct emotion that affects investor behavior triggered by events unrelated to the decision taken. Moderate body condition, full work routine, Social Factor, sadness, family factors, Lunar phases, and weather can make investors unable to analyze rationally because they are more influenced by emotions.

C. Expected emotion, is the emotion that develops because the distance is too far between expectations with the reality produced. Knowledge owned, age, character, experience, and education also influence how investors analyze stocks and make investment choices. Investors who have knowledge and education about finance and capital markets are low, will tend to not be able to properly analyze stock selection and overconfidence so tend to experience errors, not in accordance with predictions and expectations. Likewise, with character, experience and age will affect the accuracy of analysis conducted by investors and emotional maturity. In this case including culture, local wisdom of each investor

D. The more dominant investors are influenced by emotions in their investment behavior, tend to develop overconfidence behavior, representativeness bias, loss aversion, cognitive dissonance, availability bias, self-attribution bias and so on. The behavior of the bias will affect the return generated by investors. The higher the bias, the more irrational investors, the lower the return generated and the higher the likelihood of the investment losses.

\section{Figure 1: Model of Cognitive and Psychology's Investor Behavior}

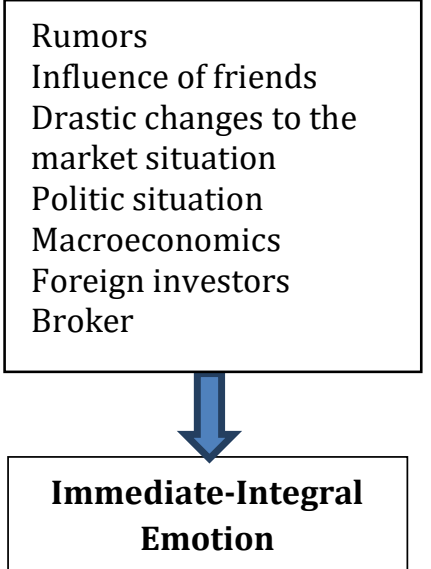

Body condition Routine work Social factors Family Sadness Lunar phases Weather

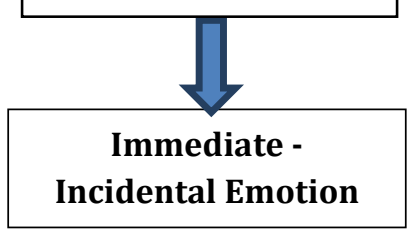

\section{Knowledge \\ Age \\ Character}

Experience

Education

Culture

Local wisdom

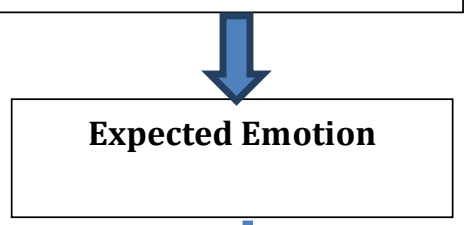

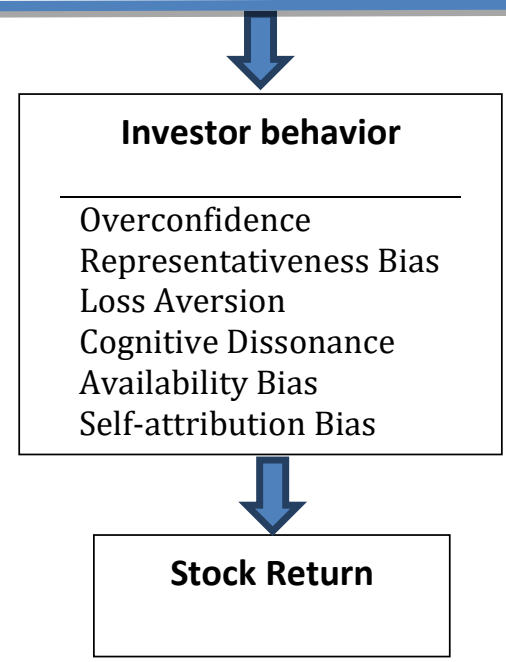




\section{Conclusion and Recommendations}

The phenomenon of biased behavior among stock investors causes their returns not to be optimal. This is essentially due to fear and greed, resulting in their analysis becoming irrational. The psychological bias of the expected emotion experienced by the informants included overconfidence, representativeness bias, loss aversion, cognitive dissonance, availability bias, and self-attribution bias, while immediate integral emotion was triggered by rumor, the influence of friends, drastic changes in the condition of the market, foreign investors, and brokers. Then, immediate incidental emotion was triggered by biological factors, social factors, mainly work, family, or friends, the weather, and sadness. The experience and willingness to keep learning, always updating the science, conducting analyses in the right way, and determining the planned targets well before taking any investment decisions represent steps to reduce the biased behavior.

Recommendations: There was interesting to the investor to update the knowledge about the capital market, update news and always make the trading plan to minimize bias behavior and to be more rational. And always thank God for everything we take from investment to minimize fear and greed that it was the most factor can make instability in behavior. The second recommendation is investor should be rational.From a psychological standpoint, investors make non-rational mistakes because the inner ability of human nature prevails to any education, training and computing power. No matter how sophisticated is the financial and statistical data, the decision has to be implemented by a human being, subjected to emotions and fears, job security constraints, etc. If these biases and errors are recurrent and predictable, that means that a rational investor can profit from non-rational decisions of some noisemakers activating in the market.

\section{References}

Ady, S. U. (2015). Manajemen Psikologi dalam Investasi Saham, Kajian Fenomenologi dalam Sentuhan Behavioral Finance. (Monika Bendatu, Ed.) (1st ed.). Jogja: CV. Andi Offset.

Ady, S. U. (2018). The Moral Values of Psychological Stability, Successful Key of Investment. In 1st International Conference on Intellectuals' Global Responsibility (ICIGR 2017) (Vol. 125, pp. 33-37). Atlantis Press.

Ady, S. U., \& Mulyaningtyas, A. (2017). Eksplorasi Tingkat Efisiensi Pasar Modal Indonesia, Studi Kasus di Bursa Efek Indonesia. Ekspektra: Jurnal Bisnis Dan Manajemen, 1(2), 103-123. https://doi.org/http://dx.doi.org/10.23159/ekt.v0i0.184

Ady, S. U., Salim, U., \& Susanto, H. (2010). Analisis Variabel yang Berpengaruh terhadap Spread Harga Saham pada Industri Manufaktur di Bursa Efek Jakarta. WACANA, 13(132).

Ady, S. U., Sudarma, M., Salim, U., \& Aisyah, S. (2013). Psychology's Factors of Stock Buying and Selling Behavior in Indonesia Stock Exchange (Phenomenology Study of Investor Behavior in Surabaya). IOSR Journal of Business and Management, 7(3), 11-22. Retrieved from www.iosrjournals.org

Badshah, W., Irshad, S., \& Hakam, U. (2016). Effect of Representativeness Bias on Investment Decision Making. Management and Administrative Sciences Review, 5(1), 26-30.

Bodnaruk, A., \& Simonov, A. (2016). Loss-averse preferences, performance, and career success of institutional investors. Review of Financial Studies, 29(11), 3140-3176. https://doi.org/10.1093/rfs/hhw053

Bogdan, R., \& Biklen, S. K. (2003). Qualitative Reseach for Education: an Introduction to theory and Method (4th ed.). Boston: Pearson.

Campbell, W. K., Goodie, A. S., \& Foster, J. D. (2004). Narcissism, Confidence, and Risk Attitude. Journal of Behavioral Decision Making, 17, 297-311. https://doi.org/10.1002/bdm.475

Cao, M., \& Wei, J. (2005). Stock Market Return: A Note on Temperature Anomaly. Journal of Banking and Finance,29(6), 1559-1573. https://doi.org/https://doi.org/10.1016/j.jbankfin.2004.06.028

Chang, T. Y., Solomon, D. H., \& Westerfield, M. M. (2016). Looking for Someone to Blame: Delegation, Cognitive Dissonance, and the Disposition Effect. Journal of Finance, 71(1), 267-302. https://doi.org/10.1111/jofi.12311

Creswell, J. W. (2007). Qualitative Inquiry and Research Design: Choosing Among Five Approaches. Book (Vol. 2nd ed). https://doi.org/10.1016/j.aenj.2008.02.005

Cunha, G. R. (2015). Cognitive Biases and Error in Decision Making. Bairro Santo Agostinho.

Damasio, A. R. (2006). Descartes' Error: Emotion, Reason, And The Human Brain (Revised). Vintage. 
Daymon, C., \& Holloway, I. (2007). ). Metode-metode Riset Kualitatif dalam Public Relation dan Marketing Communication. (S. I. Astuti, Ed.) (1st ed.). Jogjakarta: PT. Bentang Pustaka.

De Bondt, W. F. M. (1998). A Portrait of Individual Investor. European Economic Review, 42, 831-844.

Dowling, M., \& Lucey, B. M. (2008). Robust Global Mood Influence In Equity Pricing. Journal of Multinational Financial Management, $18(2), \quad 145-164$. https://doi.org/https://doi.org/10.1016/j.mulfin.2007.06.002

Emzir. (2010). Metodologi Penelitian Pendidikan: Kuantitatif dan Kualitatif. Jakarta: Rajawali Pers.

Glaser, B. G., \& Strauss, A. L. (1967). The Discovery of Grounded Theory: Strategies for Qualitative Research. Observations (Vol. 1). https://doi.org/10.2307/2575405

Guba, E. G., \& Lincoln, Y. S. (1994). Competing Paradigms in Qualitative Research. Handbook of Qualitative Research, 105-117. https://doi.org/http://www.uncg.edu/hdf/facultystaff/Tudge/Guba\%20\&\%20Lincoln\%201994.pdf

Guba, E. G., \& Lincoln, Y. S. (2004). Competing paradigms in qualitative research. Approaches to Qualitative Research: $\quad$ A Reader on Theory and Practice. https://doi.org/http://www.uncg.edu/hdf/facultystaff/Tudge/Guba\%20\&\%20Lincoln\%201994.pdf

Hagstrom, R. G. (2010). The Warren Buffett Portfolio: Membedah Keunggulan Strategi Investasi Fokus. (1st ed.). Daras Books.

Han, T. A., Pereira, L. M., Santos, F. C., \& Lenaerts, T. (2013). Why is it so hard to say sorry? BNAIC 2013: Proceedings of the 25th Benelux Conference on Artificial Intelligence, Delft, The Netherlands, November 7-8, 2013, (maY), 4-9. https://doi.org/10.1136/bmj.332.7556.1519

Hirshleifer, D., \& Shumway, T. (2003). Good Day Sunshine: Stock Return and The Weather. Journal of Finance, $\begin{array}{lcr}\text { 58(3), } & 1009-1032 . & \text { Retrieved } \\ \text { https://www.jstor.org/stable/3094570?seq=1\#page_scan_tab_contents }\end{array}$

Hu, J. (2008). Does Weather Matter? Departmental Working Papers 0809, 1(October), 1-48. Retrieved from https://ideas.repec.org/p/smu/ecowpa/0809.html

Jahanzeb, A. \& Muneer, S. (2012). Implication of behavioral finance in investment decision-making process. Information Management and Business Review, 4(10), 532

Jannah, W., \& Ady, S. U. (2017). Analisis Fundamental, Suku Bunga, Dan Overconfidence Terhadap Pengambilan Keputusan Investasi Pada Investor Di Surabaya. Ekspektra: Jurnal Bisnis Dan Manajemen, 1(2), 138-155. https://doi.org/10.1007/BF00139728.5

Loewenstein, G. (2000). Emotions in economic theory and economic behavior. The American Economic Review, 90(2), 426-432. https://doi.org/10.2307/117263

Loewenstein, Hsee, C. K., Weber, E. U., \& Welch, N. (2001). RiskAsFeelings.pdf. Psychological Bulletin, 127(2), 267-286. https://doi.org/10.1037//0033-2909 1272.267

Lucey, B. ., \& Dowling, M. (2005). The Role Of Feeling In Investor Decision making. Journal Of Economic Surveys, 19(2), 211-237. https://doi.org/10.1111/j.0950-0804.2005.00245.x

Mitroi, A. (2014). Behavioral Finance: Biased Individual Investment Decision Making; Like the Company but Dislike the Investment. Theoretical and Applied Economics, 21(1), 63-74.

Moustakas, C. (1994). Phenomenological Research Methods (1st ed.). USA: Sage Publication. Retrieved from http://methods.sagepub.com/book/phenomenological-research-methods

Muneer, S., Jahanzeb, A. \& Suwandi. (2016). Income diversification and performance: a comparison of commercial and Islamic banks of Pakistan. Abasyn Journal of Social Sciences, Special Issue, 471-485

Novemsky, N., \& Kahneman, D. (2005). The Boundaries of Loss Aversion. Journal of Marketing Research, 42(2), 119-128. https://doi.org/10.1509/jmkr.42.2.119.62292

Pompian, M. M. (2006). Behavioral Finance and Wealth Management How to Build Optimal Portfolios That Account for Investor Biases (1st ed.). New Jersey: John Wiley \& Sons.

Shefrin, H. (2001). Do investors expect higher returns from safer stocks than from riskier stocks? Journal of Psychology and Financial Markets, 2(4), 176-181.

Shefrin, H. (2005). A Behavioral Approach to Asset Pricing. Academic Press. Retrieved from https://www.elsevier.com/books/a-behavioral-approach-to-asset-pricing/shefrin/978-0-08047603-2

Shenton, A. K. (2004). Strategies for ensuring trustworthiness in qualitative research projects. Education for Information. https://doi.org/10.3233/EFI-2004-22201

Teng, C. \& Liu, V. W. (2013). The Pre Holiday Effect and Positive Emotion in The Taiwan Stock Market, Investment Analysts Journal, 42(77), 35-43. https://doi.org/10.1080/10293523.2013.11082554 
Thaler, R. H. (2005). Advances in Behavioral Finance: Vol. II (1st ed.). New Jersey: Princeton University Press, Russell Sage Foundation. https://doi.org/10.2307/2329257

Yates, J. F. (1991). Judgment and Decision Making. Englewood Cliffs, NJ: Prentice Hall. Prentice Hall. https://doi.org/10.1002/bdm.3960040107

Yuksel, A. \& Yuksel, A. (2009). Stock Return Seasonality and the Temperature Effect. International Research Journal of Finance and Economics, 34, 107-116. Retrieved from https://www.researchgate.net/publication/255663240_Stock_Return_Seasonality_and_the_Tempera ture_Effect. 